\title{
The Influence of Mason Group Composition on Optimal Field Labor's Productivity in Malang - East Java
}

\author{
Tjaturono $^{1}$
}

\begin{abstract}
The composition of labor groups is one of the main factors determining their productivity. So far, in Indonesia the labor composition is based on both the Indonesian National Standard (Standar Nasional Indonesia/ $S N I)$ of 2001 and the result of housing developers' 'trial and error test'. However, these compositions do not produce an optimal productivity.

This study is aimed at obtaining an ideal composition of a labor group and equivalent coefficient as well as actual productivity differences on productivity of the SNI 2001. The method used are field observation and interview on 260 labors from a group of the middle-class house's construction in Malang - East Java. The data obtained were processed by using descriptive statistics and statistical test for mean differences.

The results of this research show that the ideal compositions of masonry foundation and bricklaying labors are: 1 mason: 2 labors, and 1 mason: $1 \frac{1}{2}$ labors for wall plastering. The equivalent coefficients for various mason groups are also obtained. Compared with the actual productivity of SNI 2001, the field labors' productivities are $108,5 \%, 19 \%$, and $155 \%$ for masonry foundation, bricklaying, and wall plastering, respectively
\end{abstract}

Keywords - group composition, field labor's productivity, ideal and optimal, SNI of 2001, middle-class housing.

\section{INTRODUCTION}

$\mathrm{P}$ roductivity of a labor is one of the basic factors influencing competitive ability in a construction industry. The productivity of an efficient and effective labor will reduce labor time and cost, so that the contractor/developer would have a competitive advantage [24]. It means that performance of the contractor/developer is higher than competitors in terms of saving time and lower selling price.

Fundamental changes in calculating unit price is needed to measure labor productivity in housing construction, i.e. Construction Cost Analysis or Analisis Biaya Konstruksi (ABK). One of the Construction Cost Analysis is BOW Analysis (Burgelijke Openbare Werken) of 1921, which had lasted for eight decades up to $1990 \mathrm{~s}$. At this moment, the measurement of labor productivity according to the BOW of 1921 Analysis is not appropriate anymore to use, as the methods, instruments, human resources, and other factors have changed comparing with the situation at that time the BOW was planned [11], [17].

Subsequently, from 1988 to 1993, Indonesian

${ }^{1}$ Tjaturono is with the Department of Civil Engineering, Faculty of Civil Engineering and Planning, Institut Teknologi Nasional, Malang, Indonesia. E-mail: caturono@telkom.net; tjaturono@hotmail.com. government through The Center of Research and Development of Public Works Office (Pusat Litbang Dinas Pekerjaan Umum) [25] conducted a continuum of research on the labor indexes in housing area and produced a new ABK, by issuing an Indonesian National Standard of 2001 (SNI 2001). However, the labor productivity based on the composition of labor groups on the SNI of 2001 does not fulfill the expectation of developers/ contractors in Malang - East Java, as the use of the labor productivity based on the SNI 2001 has no competitive advantage [23]. In order to be efficient and effective in determining labor productivity used, developers of housing construction apply a labor productivity based on their own "test", by determining a composition of various labor groups so that they have a different labor productivity [11], [21]. Practically, the productivity used by the developers is better than SNI 2001. Nevertheless, the developers are still unsure whether the labor productivity obtained has reached the optimal productivity as it is expected and generate competitive advantage value

Research on the labor productivity conducted by Ratnayanti (2003) shows that the composition of labor is one of the main factors determining / influencing on the labor productivity in the field. That's why a research on the measurement of labor productivity with various group labor in the field is needed to obtain an optimal labor productivity from the cost as well as time point of view [10], [15], [20]. This research is conducted on the mason groups, covering masonry foundation, bricklaying, and wall plastering with various labor groups, in order to get an ideal composition of a labor group and an optimal labor productivity on a non-high rise middle-class housing construction [13] [27] as needed by the developers in Malang-East Java. By an optimal productivity of the field labor, a developer of the middle class housing has a competitive advantage value. [5], [6], [18], [22].

The study is aimed at obtaining a composition of an ideal mason group, a coefficient of the equivalent factor for the composition of mason group, as well as the difference of productivity of actual labor from the study on those of the SNI 2001. In order to achieve this, other factors affected labor productivity besides labor compositions were controlled and kept at a constant state. Those factors are building site was in normal condition so that implementation works without any constrain, standard labor force was available enough, good controlling, and materials and equipments needed for the construction process were assumed available enough. 


\section{COMPOSITION OF THE LABOR GROUP}

For field construction, a supervisor has a duty to give instruction, control the quality of work of another labor such as: mason, metal labors, and labor assistants. A supervisor should have a capability to control masons which the ideal composition is one supervisor for 10-12 masons; and one mason is aided by some labors called a group of labors [15]. However, in reality, at a field, only prolific and supportive labors who make the mason productivity achieved so that the mason has an important role. The reason is the final product of a construction work depends on the performance of the labor in each field labor, so that the productivity of field labors will be determined by composition of its labors [23].

Here are examples on the difference productivity of a masonry foundation group with a different group composition from various analyses as follows:

- Analysis of BOW from 1921 to 2000:

Composition: 0,15 supervisor, 0,1 mason leader, 1 mason, and 3 labors.

Productivity $=0,83 \mathrm{~m}^{3} /$ day /labor group

- Analysis of SNI 2001 up to now:

Composition : 0,125 supervisor, 0,1 mason leader, 1 mason, and 2,5 labors.

Productivity $=1,67 \mathrm{~m}^{3} /$ day $/$ labor group

- Analysis of Tjaturono's research finding (2005):

Composition: 0,1 supervisor, 1 mason, and 2 labors. Productivity $=3,70 \mathrm{~m}^{3} /$ day /labor group

\section{Productivity of The LABor GrouP}

Productivity can be defined as a ratio between output (result achieved) and input (resources used) or effectiveness with efficiency [2], [3], [5], [19]. The resources used to realize the result are: labors, capital, machines, equipments, raw materials, technology, etc. Among the resources, human resources has an important role in achieving a certain productivity, as instrument and technology are only a masterpiece of human resources [12]. Even Suternaister [14] in his finding concluded that about $90 \%$ of labor productivity depends on the achievement of labors and $10 \%$ depends on the progress of technology and raw materials.

Productivity of labors is a comparison of product and the role of labors (the used of human resources efficiently and effectively) in each time unit. Therefore, a productivity of human labors is a concept indicating the relationship between the working result and a certain time unit required to produce the work within a group of labor. In other words, productivity of a labor group is a quantity of time needed by a labor group or a labor team to produce a certain work volume.

\section{RESEARCH METHODS}

In this section, we describe the location of research, population, data sampling, and data analysis.

- Location of the research on the influence of labor composition to the productivity of field labor was in Malang (municipality and regency). Research was conducted from March 15, 2008 to September 15, 2008.

- Population of the research was developers of middle-class housing, who have constructed at least 200 units of middle class houses in one location. Then sampling process was done in a simple random way: four developers from six eligible developers, whereas unit analysis of the labor group sample was $20(\mathrm{~N})$ taken in a simple random way from $50-70$ house units, which were constructed by the developers and a five group are taken for each developer.

- The data collection was conducted by direct observation in the field, interviewing or both methods. For example, composition of the masonry foundation group was: 1 mason : 1 labor , 1 mason : 1 1/2 labor, 1 mason : 2 labors, 1 mason : $2^{1 / 2}$ labors and 1 mason : 3 labors. For compositions of 1 mason : $1 \frac{1}{2}$ labors are arranged by applying 2 masons : 3 labors. It means that there are two groups of masons with composition of 1 mason : 11/2 labor. Furthermore, for composition of 1 mason : $2 \frac{1}{2}$ labors are arranged by applying 2 masons : 5 labors. It means that there are two groups of masons with composition 1 mason: $2 \frac{1}{2}$ labors. Observation conducted to 20 labor groups five times in an effective six-hour work in a day. Supervising was done in the morning, mid-day and afternoon. The result of direct observation was data on productivity of each labor group composition.

- Data that had been collected from the field observation were set in a table and analyzed. The analysis was done by descriptive statistic methods, a method used to describe a set of quantitative data [9], [16]. Furthermore, some of the data are analyzed by counting the mean $(\bar{x})$; variance $\left(\mathrm{s}^{2}\right)$, deviation standard (s), and statistical test for the mean differences was used to compare labor group composition productivity.

Then, the cost of productivity is obtained for each different labor group based on the cost of mason and labor at that time. The result of cost for each composition of mason group is described in a plot showing correlation between cost and productivity of the labor group composition to achieve an optimal productivity of the labor group (effective and efficient).

\section{RESULTS AND DISCUSSION}

The result of treatment of the three kinds labor with various labor groups in a same way is taken as an example, and its composition is: 1 mason : 1 labor, 1 mason : 2 labors, 1 mason : 3 labors and 1 mason : 4 labors. Data for two other works - composition of bricklaying labor and wall plastering - are processed in the same way.

From direct observation to the field for productivity of the masonry foundation group with various labor groups, the result has been obtained, as seen in Tables 1, 2, 3, 4 and 5.

Subsequently, for masonry foundation group with various labor groups, 20 sample/data (n) are taken for each group, and if it is determined with $95 \%$ confidence level and 5\% degree of accuracy, the test for data sufficiency can be seen by the following Groeneveld [4] formula: 


$$
\mathrm{n}^{*}=\left[\frac{Z_{\alpha / 2} \cdot S}{e}\right]^{2} \text { which }: Z_{\alpha / 2}=1,96 ; \mathrm{S}=
$$

Deviation standard ; $e=0,05 \mathrm{x}$ mean productivity

Statistical test of mean difference in Table 7 indicated that there were significant differences of labor productivity among group compositions of 1 mason : 1 labor, 1 mason : 1.5 labors, and 1 mason : 2 labors $(\mathrm{p}<$ $0,05)$. But no significant difference between 1 mason : 2 labors and 1 mason : 2,5 labors and between 1 mason: 2,5 labors and 1 mason : 3 labors ( $p>0,05)$.

Further cost calculation needed to achieve productivity of the labor group each day is done by using existing daily cost at the time of study conducted, i.e.: supervisor Rp. 50.000,-, mason Rp. 40.000,- and labor Rp. 25.000,-

The calculation is based on the reality in the field that the supervisor's duty is ordering instructions, controlling masons and labors' works, whereas one yielding productivity is a mason assisted by labors supporting their works. Then the cost for each Group Compostion can be seen in Table 8 .

From Table 6 on the Labor Group Composition and Productivity Mean and Table 8 on the Labor Group Composition with Labor Productivity Cost per day, we have two plots, - i.e. one represents a relationship between mason group and productivity per day, and the other between mason group and productivity cost per $\mathrm{m}^{3}$ can be seen in Fig. 1 and 2, respectively.

From Fig. 1 and Fig. 2, it can be obtained an optimum point, a point showing the most efficient cost of mason labor with an effective productivity of working group composition, so that it can be concluded that the amount of cost as well as the most efficient labor cost in labor composition is 1 mason : 2 labors as the amount of $\mathrm{Rp}$. $23.284,-/ \mathrm{m}^{3}$ with a sufficient effectiveness of labor productivity as the amount of $4,08 \mathrm{~m}^{3} /$ day/Group. Furthermore, the same data processing is conducted also for two other mason labors - on the bricklaying and wall plastering labor group composition which its result can be seen in Table 9.

From Table 9 on the productivity mean and cost per day for bricklaying and wall plastering labor group composition, we have four plots, it can be seen in Fig. 3, 4,5 and 6 , respectively.

Besides the four Figures above, there are some labor group compositions in which their labor cost is less efficient and less productive. For example, the ideal composition of a wall plastering labor group is 1 mason : $1 \frac{1}{2}$ labor with productivity $22.30 \mathrm{~m}^{2}$ and the most efficient cost is Rp. $3.700,-/ \mathrm{m}^{2}$ comparing with composition of labor group 1 mason : 2 labors with productivity $24.40 \mathrm{~m}^{2}$ and the productivity is $\mathrm{Rp} .3 .837$,per $\mathrm{m}^{2}$.

This composition of a labor group can be used also when there is retardation or delay in work for this should be fastened. In spite of that, fastened project as a whole can be classified into activities, which are in a critical way; its duration is planned dependent to the labor productivity of the ideal labor group, substituted by productivity of larger labor based in a larger labor group composition. Although the cost for labor is larger than the efficient cost, but the precipitate can be obtained with a low additional cost, hence a crashing or trade-off is unnecessary as this in general causes a higher cost of the precipitate by additional labor group, overtime, and shift [1], [7].

Based on the calculation of mean productivity for the three masonry foundation group with various compositions, the ideal labor group with a minimal cost of manpower is determined as a basis for equivalence by giving coefficient 1 for the ideal composition. In doing so, the equivalent coefficient is obtained as shown in Table 10.

Table 10 shows the equivalent coefficient for various labor groups. This coefficient is needed to keep pace with implementation of working in different labor group compositions, because the developers do not know the optimum point between an ideal labor composition with an efficient cost and an optimal productivity. So far, in doing their works in their field with labor group compositions the developers make a composition according to their experiences or based on "trial and error" which are deemed as the most efficient and effective way.

Furthermore, the result of calculation of the productivity and cost obtained from various group compositions, are compared with the result of list analysis of labor cost of the SNI 2001 by using the equivalent coefficient shown in Table 10. This step generates a productivity difference between mason in Malang and productivity of labor of SNI 2001 shown in Table 11.

As listed on Table 11, the difference of labor group composition between this research and that of the SNI 2001 for masonry foundation, i.e.: 1 mason : 2 labor is a composition resulting an optimal productivity, whereas according to the composition of SNI 2001 is 1 mason : $2 \frac{1}{2}$ labor. The group composition difference is generated by working methods, equipments, different controlling at the research was done and before SNI 2001 was issued, hence before calculating the difference, balancing is needed first as it is shown in Table 10. By balancing the composition of masonry labor in the field from the composition 1 mason : 2 labor into 1 mason : 21/2 labor, it is obtained $108,5 \%$ productivity difference.

Moreover, after balancing wall plastering group composition into 1 mason : 1,34 labor, it is obtained $155,5 \%$ productivity difference from SNI 2001's. Whereas for bricklaying, with the same process, it is obtained $19 \%$ productivity difference from SNI 2001's. This result is aligned to a research conducted by Tjaturono, 2009 [24] stating that the improvement of mason's and wall plastering labor's productivity comparing to those of SNI 2001 is more significant than productivity improvement of bricklaying labor.

\section{CONCLUSION}

The following conclusions are based on the research of an ideal labor composition, equivalent factor, and difference productivity compare with SNI 2001. Firstly, the ideal composition of labor group and optimal labor productivity for masonry is 1 mason : 2 labors with the most efficient cost $\mathrm{Rp} 23.284$,- per $\mathrm{m}^{2}$ and productivity $4.08 \mathrm{~m}^{3}$. The ideal composition for bricklaying is 1 mason : 2 labors with the most efficient cost Rp 65.517,per $\mathrm{m}^{2}$ and productivity $1,45 \mathrm{~m}^{3}$ per day. The ideal composition for wall plastering group is 1 mason : $1 \frac{1}{2}$ 
labors with the most efficient cost Rp. 3.700,- per $\mathrm{m}^{2}$ and productivity $27,30 \mathrm{~m}^{2}$ per day.

Secondly, the research found an equivalent factor for various mason groups. These equivalent coefficients are based on ideal composition of labor groups with minimum cost as the basis, and it is pointed out by 1 for technical calculation. The coefficient equivalencies for other compositions are based on a comparison between achieved productivity of each labor composition group and the productivity of the ideal ones. Based on the principle, the ideal labor composition for masonry was 1 mason : 2 labors so that equivalent coefficient for the other labor composition groups are: 0.68 for 1 mason : 1 labor, 0,83 for 1 mason : $1 \frac{1}{2}$ masons, 1.05 for 1 mason : $2 \frac{1}{2}$ labors, and 1.06 for 1 mason : 3 labors. The ideal labor composition for bricklaying was 1 mason : 2 labors, so that equivalent coefficient for the other labor composition groups are 0.70 for 1 mason : 1 labor, 0.84 for 1 mason : $1 \frac{1}{2}$ labors, and 1.03 for 1 mason : 1 $1 \frac{1}{2}$ labors. The ideal labor composition for wall plastering was 1 mason : $1 \frac{1}{2}$ labors so that equivalent coefficient for the other labor composition groups are 0.74 for 1 mason : 1 labor, 1.1 for 1 mason : 2 labors, and 1.11 for 1 mason : 21/2 labors.

Finally, after balancing is done for labor composition of the research finding on SNI 2001 using equivalent coefficient mention above, it was found that labor productivity is $4.17 \mathrm{~m}^{3}$ per day, $1.49-1.50 \mathrm{~m}^{3}$ per day, and $20.54 \mathrm{~m}^{2}$ per day for masonry foundation, bricklaying, and wall plastering respectively. Therefore, the difference labor productivity between the research finding and SNI 2001 is $108.5 \%$ for masonry, $19 \%$ for bricklaying, and $155 \%$ for wall plastering.

\section{SUGGESTION}

Further research needs to be conducted to obtain an equivalent coefficient for all labor groups, but mason group, such as a labor group for concrete work, carpenter, install floor tile, and install roof tile, etc., and to determine the equivalent coefficient between labor productivity in Java and outside Java. So that the labor productivity standard (Standar Produktivitas Tenaga Kerja Nasional Indonesia - SNI) can be more realistic and applicable for each regional condition with its different human resources' capability.

\section{REFERENCE}

[1] Alifen, Ratna, S., 2000, 'Analisa "What If" Sebagai Metode Antisipasi Keterlambatan Durasi Proyek', Dimensi Teknik Sipil, Universitas Kristen Petra, Surabaya, Volume 1, No. 2, September, pp. 103-113.

[2] Bain, D., 1983, The Productivity Prescription, The Manager's Buide Improving Productivity and Profit, Mc Graw-Hill Book Company, New York.

[3] Gasperz, Z., 2005, Manajemen Produktivitas Total, PT. Gramedia Pustaka Utama, Jakarta.

[4] Groeneveld, R.A., 1988, Introductory Statistical Methods: An Integrated Approach Using Minitab, PWS-Kent Publishing Company, Boston.

[5] Hafid, 1995, 'Studi Pengukuran Produktivitas Tenaga Kerja dengan Menggunakan Pendekatan Analisa Rasio', Usahawan, No. 04, Tahun XXIV, April.
[6] John dan Lowe, 1987, 'The Measurement of Productivity in the Construction Industry', Journal of Construction Management and Economics, Department of Building, Heriot Wate University Edinburgh, Volume 5: 101-113.

[7] Johan J. 1998, 'Trade-off Waktu dan Biaya pada Proyek Konstruksi, Studi Kasus pada Proyek Kantor Bank Metro', Jurnal Teknik Sipil Fakultas Teknik Universitas Tarumanagara, No. 3, Tahun ke IV, November, pp. 277-298.

[8] Kerzner, Harold, 2006, Project Management: A System Approach to Planning, Scheduling and Controlling, Van Nostrand Reinhold.

[9] Nazir, Moch., 2004, Metode Penelitian, Jakarta, Ghalia, Indonesia.

[10] Ratnayanti, R., 2003, 'Produktivitas Tenaga Konstruksi pada Setiap Jenjang Keahlian di Lapangan', Jurnal Teknik Sipil ITB, Volume 1, No. 1, April, pp. 33-42.

[11] Rostiyanti, S.F., 2001, 'Pengaruh Umur dan Pengalaman terhadap Koefisien Tukang Batu pada Pekerjaan Pasangan Dinding Batu merah', Jurnal Teknik Sipil Universitas Tarumanegara, no. 3, November, Jakarta, pp. 329-338.

[12] Setyanto E., Peter F. Kaming, Anna N. Wikantyasningsih, 1998, 'Studi Tentang Perbandingan Produktivitas Tenaga Kerja Konstruksi di Yogyakarta dan Sekitarnya', Konferensi Manajemen Proyek Konstruksi di Universitas Atmajaya Yogyakarta Kerjasama dengan HAMKI, pp. 57-68.

[13] Simanungkalit, Panangian, 2004, Bisnis Property Menuju Crash Lagi? Penerbit Pusat Studi Properti Indonesia.

[14] Siswanto, B., 1989, Manajemen Tenaga Kerja, Sinar Baru, Bandung.

[15] Soeharto, 2001, Manajemen Proyek, Erlangga.

[16] Sugiono, 2002, Metode Penelitian Bisnis, Bandung.

[17] Suryanto, Krishna Pribadi, 1997, 'Model Produktivitas Pekerjaan Konstruksi Bangunan Gedung Bertingkat di Indonesia', Laporan Penelitian, ITB, Bandung.

[18] Sutoto, 2009, Siasat di Tengah Krisis, Koran Kompas, Liputan Khusus, 27 Maret.

[19] Tangen, Stefan, 2002, 'Understanding The Concept of Productivity', Proceedings of the 7th Asia Pacific Industrial Engineering and Management Sustems Conference, Taipei.

[20] Tjaturono, 2002, 'Penerapan Sistem Modul dan Metode Fast Track sebagai Alternatif dalam Peningkatan Efektifitas dan Efisiensi Pembangunan Rumah Menengah' Proceeding Seminar Nasional Pasca Sarjana II ITS, pp. C6-1 - C6-9.

[21] Tjaturono, Nadjadji A., dan Indrasurya B.M., 2004, 'Evaluasi Produktivitas Tenaga Kerja Berdasarkan Delapan Faktor Internal Dibandingkan Dengan Standar BOW 1921 dan SNI 2001 pada Pembangunan Rumah Menengah di Jawa Timur', Jurnal Teknik Sipil Universitas Tarumanagara Jakarta, Maret 2004, pp. 91-109.

[22] Tjaturono, 2004, 'Penerapan Produktivitas Tenaga Kerja Aktual dan Modifikasi Penjadwalan dengan Metode Fast Track untuk Mereduksi Biaya dan Waktu Pembangunan Perumahan' Makalah Seminar REI Jatim, 16 Desember, Hotel Shangri-la, Surabaya.

[23] Tjaturono, Nadjadji A., Indrasurya, B.M., Maziah Ismail, 2005, "The Development of Actual Labour Productivity Measurement Model for Medium Cost Housing in Malang, East Java, Indonesia", Jurnal Sains dan Teknologi Kejuruteraan, KUITTHO, Malaysia.

[24] Tjaturono, Indrasurya, B.M. 2009, 'Pengembangan Metode Fast Track untuk Mereduksi Waktu dan Biaya Pelaksanaan Proyek Studi Kasus Rumah Menengah di Malang, Jawa Timur' Media Komunikasi Teknik Sipil, Badan Kejuruan Sipil PII dan Badan Musyawarah Pendidikan Tinggi Teknik Sipil Seluruh Indonesia, Semarang, Tahun 17, No. 1, Februari, pp. 39-54.

[25] Pusat Litbang Pemukiman, Badan Litbang Pekerjaan Umum Departemen Pekerjaan Umum, 1991, 'Penelitian Analisa Biaya Konstruksi Tahun 1990/1991', Laporan Akhir, Tim Peneliti Analisa Biaya Konstruksi.

[26] Badan Standardisasi Nasional Indonesia, 2001, Kumpulan Analisa Biaya Konstruksi Bangunan Gedung dan Perumahan.

[27] Menteri Negara Perumahan Rakyat Republik Indonesia, 1995, Pedoman Pembangunan Perumahan dan Permukiman dengan Lingkungan Hunian yang Berimbang. 
TABLE 1.

Composition of Labor Group, Daily Productivity, Total Productivity Mean, Deviation Standard (S)

\begin{tabular}{|c|c|c|c|c|c|c|c|c|c|c|}
\hline \multirow[t]{2}{*}{ No. } & \multirow{2}{*}{$\begin{array}{l}\text { Labor } \\
\text { Group } \\
\text { Masonry }\end{array}$} & \multirow[t]{2}{*}{ Composition } & \multicolumn{5}{|c|}{ Labor Group Productivity } & \multirow{2}{*}{$\begin{array}{l}\text { Mean } \\
\text { Group } \\
\left(\mathrm{m}^{3} / \text { day }\right)\end{array}$} & \multirow{2}{*}{$\begin{array}{c}\text { Total } \\
\text { Productivity } \\
\text { Mean } \\
\left(\mathrm{m}^{3} / \text { day }\right)\end{array}$} & \multirow{2}{*}{$\begin{array}{c}\mathrm{S} \\
\text { (Deviation- } \\
\text { Standard) }\end{array}$} \\
\hline & & & 1 & 2 & 3 & 4 & 5 & & & \\
\hline 1 & Group 1 & \multirow{20}{*}{$1 \mathrm{~ms}: 1 \mathrm{lb}$} & 2,40 & 2,52 & 2,44 & 2,55 & 2,52 & 2,49 & \multirow{20}{*}{2,76} & \multirow{20}{*}{0,28} \\
\hline 2 & Group 2 & & 2,72 & 2,80 & 2,84 & 2,94 & 2,90 & 2,84 & & \\
\hline 3 & Group 3 & & 2,70 & 2,90 & 2,90 & 2,80 & 3,14 & 2,89 & & \\
\hline 4 & Group 4 & & 3,24 & 3,30 & 3,20 & 3,24 & 3,30 & 3,26 & & \\
\hline 5 & Group 5 & & 2,60 & 2,50 & 2,60 & 2,70 & 2,50 & 2,58 & & \\
\hline 6 & Group 6 & & 2,72 & 2,94 & 2,90 & 2,60 & 2,88 & 2,81 & & \\
\hline 7 & Group 7 & & 2,60 & 2,65 & 2,75 & 2,60 & 2,80 & 2,68 & & \\
\hline 8 & Group 8 & & 2,70 & 2,65 & 2,42 & 2,35 & 2,60 & 2,54 & & \\
\hline 9 & Group 9 & & 2,85 & 2,95 & 3,10 & 2,90 & 3,05 & 2,97 & & \\
\hline 10 & Group 10 & & 3,45 & 3,60 & 3,30 & 3,55 & 3,40 & 3,46 & & \\
\hline 11 & Group 11 & & 2,80 & 2,75 & 2,80 & 2,95 & 2,90 & 2,84 & & \\
\hline 12 & Group 12 & & 2,50 & 2,60 & 2,60 & 2,50 & 2,60 & 2,56 & & \\
\hline 13 & Group 13 & & 3,00 & 3,05 & 3,20 & 3,10 & 3,40 & 3,15 & & \\
\hline 14 & Group 14 & & 2,65 & 2,50 & 2,50 & 2,60 & 2,50 & 2,55 & & \\
\hline 15 & Group 15 & & 2,90 & 2,80 & 3,05 & 2,95 & 2,75 & 2,89 & & \\
\hline 16 & Group 16 & & 2,60 & 2,40 & 2,70 & 2,55 & 2,75 & 2,60 & & \\
\hline 17 & Group 17 & & 2,40 & 2,50 & 2,65 & 2,40 & 2,55 & 2,50 & & \\
\hline 18 & Group 18 & & 2,50 & 2,65 & 2,60 & 2,70 & 2,40 & 2,57 & & \\
\hline 19 & Group 19 & & 2,60 & 2,65 & 2,40 & 2,75 & 2,50 & 2,58 & & \\
\hline 20 & Group 20 & & 2,45 & 2,40 & 2,40 & 2,45 & 2,45 & 2,43 & & \\
\hline
\end{tabular}

TABLE 2.

Labor Group Composition, Daily Productivity, Total Productivity Mean, Deviation Standar (S)

\begin{tabular}{|c|c|c|c|c|c|c|c|c|c|c|}
\hline \multirow[t]{2}{*}{ No. } & \multirow{2}{*}{$\begin{array}{l}\text { Labor } \\
\text { Group } \\
\text { Masonry }\end{array}$} & \multirow[t]{2}{*}{ Composition } & \multicolumn{5}{|c|}{ Labor Group Productivity } & \multirow{2}{*}{$\begin{array}{c}\text { Mean } \\
\text { Group } \\
\left(\mathrm{m}^{3} / \text { day }\right)\end{array}$} & \multirow{2}{*}{$\begin{array}{c}\text { Total } \\
\text { Productivity } \\
\text { Mean } \\
\left(\mathrm{m}^{3} / \text { day }\right)\end{array}$} & \multirow{2}{*}{$\begin{array}{c}\mathrm{S} \\
\text { (Deviation- } \\
\text { Standard) }\end{array}$} \\
\hline & & & 1 & 2 & 3 & 4 & 5 & & & \\
\hline 1 & Group 1 & \multirow{20}{*}{$1 \mathrm{~ms}: 1 \frac{1}{2} \mathrm{lb}$} & 3,00 & 2,90 & 2,95 & 3,10 & 3,00 & 2,99 & \multirow{20}{*}{3,393} & \multirow{20}{*}{0,29} \\
\hline 2 & Group 2 & & 3,40 & 3,60 & 3,70 & 3,50 & 3,40 & 3,52 & & \\
\hline 3 & Group 3 & & 3,60 & 3,40 & 3,50 & 3,70 & 3,60 & 3,56 & & \\
\hline 4 & Group 4 & & 3,70 & 3,50 & 3,70 & 3,40 & 3,90 & 3,64 & & \\
\hline 5 & Group 5 & & 3,20 & 3,40 & 3,40 & 3,30 & 3,20 & 3,30 & & \\
\hline 6 & Group 6 & & 3,60 & 3,45 & 3,65 & 3,70 & 3,25 & 3,53 & & \\
\hline 7 & Group 7 & & 3,50 & 3,62 & 3,30 & 3,70 & 3,50 & 3,52 & & \\
\hline 8 & Group 8 & & 3,10 & 2,90 & 2,90 & 3,20 & 3,10 & 3,04 & & \\
\hline 9 & Group 9 & & 3,50 & 3,70 & 3,55 & 3,45 & 3,80 & 3,60 & & \\
\hline 10 & Group 10 & & 3,90 & 4,10 & 4,40 & 4,25 & 4,05 & 4,14 & & \\
\hline 11 & Group 11 & & 3,45 & 3,60 & 3,45 & 3,60 & 3,70 & 3,56 & & \\
\hline 12 & Group 12 & & 2,90 & 3,30 & 3,20 & 3,20 & 3,40 & 3,20 & & \\
\hline 13 & Group 13 & & 3,60 & 3,70 & 3,60 & 3,50 & 3,70 & 3,62 & & \\
\hline 14 & Group 14 & & 3,10 & 3,00 & 3,25 & 3,30 & 3,15 & 3,16 & & \\
\hline 15 & Group 15 & & 3,70 & 3,40 & 3,50 & 3,60 & 3,65 & 3,57 & & \\
\hline 16 & Group 16 & & 3,50 & 3,60 & 3,40 & 3,60 & 3,40 & 3,50 & & \\
\hline 17 & Group 17 & & 3,00 & 2,90 & 2,90 & 3,20 & 3,00 & 3,00 & & \\
\hline 18 & Group 18 & & 3,20 & 3,10 & 3,20 & 3,40 & 3,20 & 3,22 & & \\
\hline 19 & Group 19 & & 3,10 & 3,20 & 3,20 & 3,40 & 3,20 & 3,22 & & \\
\hline 20 & Group 20 & & 3,00 & 2,85 & 3,10 & 2,95 & 2,90 & 2,96 & & \\
\hline
\end{tabular}


TABLE 3.

Labor Group Composition, Daily Productivity, Total Productivity Mean, Deviation Standar (S)

\begin{tabular}{|c|c|c|c|c|c|c|c|c|c|c|}
\hline \multirow[t]{2}{*}{ No. } & \multirow{2}{*}{$\begin{array}{l}\text { Labor } \\
\text { Group } \\
\text { Masonry }\end{array}$} & \multirow[t]{2}{*}{ Composition } & \multicolumn{5}{|c|}{$\begin{array}{l}\text { Labor Group Productivity } \\
\qquad \mathrm{m}^{3} / \text { day }\end{array}$} & \multirow{2}{*}{$\begin{array}{c}\text { Mean } \\
\text { Group } \\
\left(\mathrm{m}^{3} / \text { day }\right)\end{array}$} & \multirow{2}{*}{$\begin{array}{c}\text { Total } \\
\text { Productivity } \\
\text { Mean } \\
\left(\mathrm{m}^{3} / \text { day }\right)\end{array}$} & \multirow{2}{*}{$\begin{array}{c}\text { S } \\
\text { (Deviation- } \\
\text { Standard) }\end{array}$} \\
\hline & & & 1 & 2 & 3 & 4 & 5 & & & \\
\hline 1 & Group 1 & \multirow{20}{*}{$1 \mathrm{~ms}: 2 \mathrm{lb}$} & 3,65 & 3,40 & 3,55 & 3,60 & 3,45 & 3,53 & \multirow{20}{*}{4,08} & \multirow{20}{*}{0,325} \\
\hline 2 & Group 2 & & 4,00 & 4,30 & 4,20 & 4,15 & 4,20 & 4,17 & & \\
\hline 3 & Group 3 & & 4,20 & 4,10 & 4,20 & 4,40 & 4,15 & 4,21 & & \\
\hline 4 & Group 4 & & 4,45 & 4,20 & 4,30 & 4,50 & 4,35 & 4,36 & & \\
\hline 5 & Group 5 & & 4,10 & 3,90 & 4,30 & 4,20 & 3,95 & 4,09 & & \\
\hline 6 & Group 6 & & 4,10 & 4,30 & 4,10 & 4,25 & 4,00 & 4,15 & & \\
\hline 7 & Group 7 & & 4,10 & 4,40 & 4,20 & 3,90 & 4,10 & 4,14 & & \\
\hline 8 & Group 8 & & 3,80 & 3,75 & 3,95 & 3,65 & 3,70 & 3,77 & & \\
\hline 9 & Group 9 & & 4,05 & 4,40 & 4,20 & 4,35 & 4,25 & 4,25 & & \\
\hline 10 & Group 10 & & 5,10 & 4,65 & 4,85 & 5,00 & 5,05 & 4,93 & & \\
\hline 11 & Group 11 & & 4,05 & 4,10 & 4,30 & 4,40 & 4,15 & 4,20 & & \\
\hline 12 & Group 12 & & 3,90 & 4,00 & 4,05 & 3,80 & 3,95 & 3,94 & & \\
\hline 13 & Group 13 & & 4,55 & 4,20 & 4,25 & 4,20 & 4,40 & 4,32 & & \\
\hline 14 & Group 14 & & 3,80 & 4,00 & 3,95 & 3,90 & 4,00 & 3,93 & & \\
\hline 15 & Group 15 & & 4,15 & 4,20 & 4,10 & 4,40 & 4,20 & 4,21 & & \\
\hline 16 & Group 16 & & 4,00 & 4,20 & 4,15 & 4,20 & 4,10 & 4,13 & & \\
\hline 17 & Group 17 & & 3,60 & 3,75 & 3,60 & 3,80 & 3,90 & 3,73 & & \\
\hline 18 & Group 18 & & 3,95 & 3,90 & 4,20 & 4,05 & 4,10 & 4,04 & & \\
\hline 19 & Group 19 & & 4,20 & 4,00 & 3,90 & 4,15 & 4,05 & 4,06 & & \\
\hline 20 & Group 20 & & 3,40 & 3,35 & 3,50 & 3,30 & 3,45 & 3,40 & & \\
\hline
\end{tabular}

ms : mason, lb : labor

TABLE 4.

Labor Group Composition, Daily Productivity, Total Productivity Mean, Deviation Standar (S)

\begin{tabular}{|c|c|c|c|c|c|c|c|c|c|c|}
\hline \multirow[t]{2}{*}{ No. } & \multirow{2}{*}{$\begin{array}{l}\text { Labor } \\
\text { Group } \\
\text { Masonry }\end{array}$} & \multirow[t]{2}{*}{ Composition } & \multicolumn{5}{|c|}{ Labor Group Productivity } & \multirow{2}{*}{$\begin{array}{c}\text { Mean } \\
\text { Group } \\
\left(\mathrm{m}^{3} / \text { day }\right)\end{array}$} & \multirow{2}{*}{$\begin{array}{c}\text { Total } \\
\text { Productivity } \\
\text { Mean } \\
\left(\mathrm{m}^{3} / \text { day }\right)\end{array}$} & \multirow{2}{*}{$\begin{array}{c}\text { S } \\
\text { (Deviation- } \\
\text { Standard) }\end{array}$} \\
\hline & & & 1 & 2 & 3 & 4 & 5 & & & \\
\hline 1 & Group 1 & \multirow{20}{*}{$1 \mathrm{~ms}: 2 \frac{1}{2} \mathrm{lb}$} & 3,65 & 3,85 & 3,75 & 3,85 & 3,90 & 3,80 & \multirow{20}{*}{4.26} & \multirow{20}{*}{0.325} \\
\hline 2 & Group 2 & & 4,20 & 4,50 & 4,35 & 4,40 & 4,45 & 4,38 & & \\
\hline 3 & Group 3 & & 4,30 & 4,45 & 4,15 & 4,60 & 4,55 & 4,41 & & \\
\hline 4 & Group 4 & & 4,95 & 4,90 & 5,10 & 4,90 & 4,95 & 4,96 & & \\
\hline 5 & Group 5 & & 4,05 & 4,15 & 4,10 & 4,20 & 4,15 & 4,13 & & \\
\hline 6 & Group 6 & & 4,20 & 4,15 & 4,60 & 4,40 & 4,45 & 4,36 & & \\
\hline 7 & Group 7 & & 4,50 & 4,20 & 4,30 & 4,50 & 4,10 & 4,32 & & \\
\hline 8 & Group 8 & & 3,90 & 4,00 & 3,95 & 4,20 & 4,05 & 4,02 & & \\
\hline 9 & Group 9 & & 4,45 & 4,30 & 4,35 & 4,55 & 4,70 & 4,47 & & \\
\hline 10 & Group 10 & & 5,00 & 5,20 & 4,90 & 4,80 & 5,00 & 4,98 & & \\
\hline 11 & Group 11 & & 4,40 & 4,20 & 4,40 & 4,60 & 4,30 & 4,38 & & \\
\hline 12 & Group 12 & & 3,95 & 4,10 & 4,00 & 4,20 & 4,15 & 4,08 & & \\
\hline 13 & Group 13 & & 4,65 & 4,40 & 4,55 & 4,50 & 4,75 & 4,57 & & \\
\hline 14 & Group 14 & & 4,15 & 4,35 & 3,80 & 3,90 & 4,10 & 4,06 & & \\
\hline 15 & Group 15 & & 4,35 & 4,45 & 4,70 & 4,25 & 4,40 & 4,43 & & \\
\hline 16 & Group 16 & & 4,00 & 4,00 & 4,40 & 4,00 & 4,30 & 4,14 & & \\
\hline 17 & Group 17 & & 3,80 & 4,15 & 4,10 & 3,90 & 3,95 & 3,98 & & \\
\hline 18 & Group 18 & & 4,00 & 4,10 & 4,40 & 3,90 & 4,20 & 4,12 & & \\
\hline 19 & Group 19 & & 4,20 & 4,00 & 4,30 & 4,10 & 4,00 & 4,12 & & \\
\hline 20 & Group 20 & & 3,55 & 3,50 & 3,50 & 3,65 & 3,40 & 3,52 & & \\
\hline
\end{tabular}

ms : mason, lb : labor 
TABLE 5 .

Labor Group Composition, Daily Productivity, Total Productivity Mean, Deviation Standar (S)

\begin{tabular}{|c|c|c|c|c|c|c|c|c|c|c|}
\hline \multirow[t]{2}{*}{ No. } & \multirow{2}{*}{$\begin{array}{l}\text { Labor } \\
\text { Group } \\
\text { Masonry }\end{array}$} & \multirow[t]{2}{*}{ Composition } & \multicolumn{5}{|c|}{$\begin{array}{l}\text { Labor Group Productivity } \\
\qquad \mathrm{m}^{3} / \text { day }\end{array}$} & \multirow{2}{*}{$\begin{array}{c}\text { Mean } \\
\text { Group } \\
\left(\mathrm{m}^{3} / \text { day }\right) \\
\end{array}$} & \multirow{2}{*}{$\begin{array}{c}\text { Total } \\
\text { Productivity } \\
\text { Mean } \\
\left(\mathrm{m}^{3} / \text { day }\right)\end{array}$} & \multirow{2}{*}{$\begin{array}{c}\text { S } \\
\text { (Deviation- } \\
\text { Standard) }\end{array}$} \\
\hline & & & 1 & 2 & 3 & 4 & 5 & & & \\
\hline 1 & Group 1 & \multirow{20}{*}{$1 \mathrm{~ms}: 3 \mathrm{lb}$} & 4,00 & 3,90 & 4,10 & 3,80 & 4,20 & 4,00 & \multirow{20}{*}{4,32} & \multirow{20}{*}{0,34} \\
\hline 2 & Group 2 & & 4,30 & 4,20 & 4,20 & 4,40 & 4,45 & 4,31 & & \\
\hline 3 & Group 3 & & 4,25 & 4,60 & 4,70 & 4,40 & 4,50 & 4,49 & & \\
\hline 4 & Group 4 & & 4,85 & 4,65 & 4,55 & 4,90 & 4,50 & 4,69 & & \\
\hline 5 & Group 5 & & 4,15 & 4,20 & 4,40 & 4,15 & 4,30 & 4,24 & & \\
\hline 6 & Group 6 & & 4,30 & 4,15 & 4,50 & 4,30 & 4,25 & 4,30 & & \\
\hline 7 & Group 7 & & 4,40 & 4,30 & 4,50 & 4,00 & 4,20 & 4,28 & & \\
\hline 8 & Group 8 & & 4,10 & 4,05 & 4,15 & 4,00 & 4,05 & 4,07 & & \\
\hline 9 & Group 9 & & 4,55 & 4,80 & 4,60 & 4,50 & 4,70 & 4,63 & & \\
\hline 10 & Group 10 & & 5,40 & 5,25 & 5,45 & 5,10 & 4,90 & 5,22 & & \\
\hline 11 & Group 11 & & 4,65 & 4,30 & 4,70 & 4,20 & 4,50 & 4,47 & & \\
\hline 12 & Group 12 & & 4,15 & 4,20 & 3,90 & 4,15 & 4,10 & 4,10 & & \\
\hline 13 & Group 13 & & 4,80 & 4,90 & 4,20 & 4,70 & 4,80 & 4,68 & & \\
\hline 14 & Group 14 & & 4,00 & 4,10 & 4,30 & 4,05 & 4,00 & 4,09 & & \\
\hline 15 & Group 15 & & 4,35 & 4,55 & 4,70 & 4,60 & 4,40 & 4,52 & & \\
\hline 16 & Group 16 & & 4,10 & 4,30 & 4,35 & 4,25 & 4,30 & 4,26 & & \\
\hline 17 & Group 17 & & 4,15 & 4,00 & 4,15 & 4,00 & 3,90 & 4,04 & & \\
\hline 18 & Group 18 & & 4,10 & 4,15 & 4,45 & 4,05 & 4,10 & 4,17 & & \\
\hline 19 & Group 19 & & 4,20 & 4,10 & 4,15 & 4,20 & 4,25 & 4,18 & & \\
\hline 20 & Group 20 & & 3,75 & 3,70 & 3,50 & 3,65 & 3,55 & 3,63 & & \\
\hline
\end{tabular}

TABLE 6.

Labor Group Composition, Mean Productivity, Data Diversity, Deviation Standard (S), Dan Data Sufficiency

\begin{tabular}{cllcccc}
\hline No & $\begin{array}{c}\text { Kind of Labor } \\
\text { Group }\end{array}$ & $\begin{array}{c}\text { Group } \\
\text { Composition }\end{array}$ & $\begin{array}{c}\text { Mean } \\
\text { Productivity } \\
\left(\mathrm{m}^{3}\right)\end{array}$ & $\begin{array}{c}\mathrm{S}^{2} \text { (Data } \\
\text { diversity })\end{array}$ & $\begin{array}{c}\text { S ( Deviation } \\
\text { Standard) }\end{array}$ & $\begin{array}{c}\text { N* Condition of Data } \\
\text { Sufficiency }\end{array}$ \\
\hline 1 & Masonry & $1 \mathrm{~ms}: 1 \mathrm{lb}$ & 2,76 & 0,091 & 0,28 & 15,81 \\
2 & Masonry & $1 \mathrm{~ms}: 1 \frac{1}{1} \mathrm{lb}$ & 3,39 & 0,085 & 0,29 & 11,22 \\
3 & Masonry & $1 \mathrm{~ms}: 2 \mathrm{lb}$ & 4,08 & 0,104 & 0,325 & 9,75 \\
4 & Masonry & $1 \mathrm{~ms}: 2 \frac{1}{2} \mathrm{lb}$ & 4,26 & 0,120 & 0,325 & 8,94 \\
5 & Masonry & $1 \mathrm{~ms}: 3 \mathrm{lb}$ & 4,32 & 0,113 & 0,34 & 9,52 \\
\hline $\mathrm{ms}=$ & & & &
\end{tabular}

TABLE 7.

DifFERENCE MEAN AMONG LABOR COMPOSITION PRODUCTIVITY

\begin{tabular}{|c|c|c|c|c|c|c|}
\hline \multirow{3}{*}{ (I) Composition } & \multirow{3}{*}{ (J) Composition } & \multirow{3}{*}{ Mean Difference (I-J) } & \multirow{3}{*}{ Std. Error } & \multirow{3}{*}{ Sig. } & \multicolumn{2}{|c|}{$95 \%$ Confidence Interval } \\
\hline & & & & & Lower & Upper \\
\hline & & & & & Bound & Bound \\
\hline \multirow[t]{4}{*}{$1 \mathrm{~ms}: 1 \mathrm{lb}$} & $1 \mathrm{~ms}: 1.5 \mathrm{lb}$ & -0.633 & 0.10028 & 0 & -0.8321 & -0.4339 \\
\hline & $1 \mathrm{~ms}: 2 \mathrm{lb}$ & -1.3185 & 0.10028 & 0 & -1.5176 & -1.1194 \\
\hline & $2 \mathrm{~ms}: 2.5 \mathrm{lb}$ & -1.502 & 0.10028 & 0 & -1.7011 & -1.3029 \\
\hline & $2 \mathrm{~ms}: 3 \mathrm{lb}$ & -1.559 & 0.10028 & 0 & -1.7581 & -1.3599 \\
\hline \multirow[t]{4}{*}{$1 \mathrm{~ms}: 1.5 \mathrm{lb}$} & $1 \mathrm{~ms}: 1 \mathrm{lb}$ & 0.633 & 0.10028 & 0 & 0.4339 & 0.8321 \\
\hline & $1 \mathrm{~ms}: 2 \mathrm{lb}$ & -0.6855 & 0.10028 & 0 & -0.8846 & -0.4864 \\
\hline & $2 \mathrm{~ms}: 2.5 \mathrm{lb}$ & -0.869 & 0.10028 & 0 & -1.0681 & -0.6699 \\
\hline & $2 \mathrm{~ms}: 3 \mathrm{lb}$ & -0.926 & 0.10028 & 0 & -1.1251 & -0.7269 \\
\hline \multirow[t]{4}{*}{$1 \mathrm{~ms}: 2 \mathrm{lb}$} & $1 \mathrm{~ms}: 1 \mathrm{lb}$ & 1.3185 & 0.10028 & 0 & 1.1194 & 1.5176 \\
\hline & $1 \mathrm{~ms}: 1.5 \mathrm{lb}$ & 0.6855 & 0.10028 & 0 & 0.4864 & 0.8846 \\
\hline & $2 \mathrm{~ms}: 2.5 \mathrm{lb}$ & -0.1835 & 0.10028 & 0.07 & -0.3826 & 0.0156 \\
\hline & $2 \mathrm{~ms}: 3 \mathrm{lb}$ & -0.2405 & 0.10028 & 0.018 & -0.4396 & -0.0414 \\
\hline \multirow[t]{4}{*}{$1 \mathrm{~ms}: 2.5 \mathrm{lb}$} & $1 \mathrm{~ms}: 1 \mathrm{lb}$ & 1.502 & 0.10028 & 0 & 1.3029 & 1.7011 \\
\hline & $1 \mathrm{~ms}: 1.5 \mathrm{lb}$ & 0.869 & 0.10028 & 0 & 0.6699 & 1.0681 \\
\hline & $2 \mathrm{~ms}: 2 \mathrm{lb}$ & 0.1835 & 0.10028 & 0.07 & -0.0156 & 0.3826 \\
\hline & $2 \mathrm{~ms}: 3 \mathrm{lb}$ & -0.057 & 0.10028 & 0.571 & -0.2561 & 0.1421 \\
\hline \multirow[t]{4}{*}{$1 \mathrm{~ms}: 3 \mathrm{lb}$} & $1 \mathrm{~ms}: 1 \mathrm{lb}$ & 1.559 & 0.10028 & 0 & 1.3599 & 1.7581 \\
\hline & $1 \mathrm{~ms}: 1.5 \mathrm{lb}$ & 0.926 & 0.10028 & 0 & 0.7269 & 1.1251 \\
\hline & $2 \mathrm{~ms}: 2 \mathrm{lb}$ & 0.2405 & 0.10028 & 0.018 & 0.0414 & 0.4396 \\
\hline & $2 \mathrm{~ms}: 2.5 \mathrm{lb}$ & 0.057 & 0.10028 & 0.571 & -0.1421 & 0.2561 \\
\hline
\end{tabular}


TABLE 8.

LABOR GROUP COMPOSITION, LABOR GROUP PRODUCTION COST, PRODUCTIVITY COST PER UNIT

\begin{tabular}{|c|c|c|c|c|c|}
\hline No & $\begin{array}{l}\text { Labor Group } \\
\text { Composition }\end{array}$ & Cost detail & $\begin{array}{c}\text { Labor Group } \\
\text { Production Cost } \\
\text { (Per day) } \\
\end{array}$ & $\begin{array}{c}\text { Productivity per } \\
\text { day } \\
\left(\mathrm{m}^{3}\right) \\
\end{array}$ & $\begin{array}{l}\text { Productivity Cost per unit } \\
\qquad\left(\mathrm{Rp} / \mathrm{m}^{3}\right)\end{array}$ \\
\hline 1 & $1 \mathrm{~ms}: 1 \mathrm{lb}$ & $\begin{array}{l}0,1 \text { supervisor : } 5.000,- \\
1 \text { mason : } 40.000,- \\
1 \text { labor : } 25.000,-\end{array}$ & $70.000,-$ / day & 2,76 & $\frac{70.000}{2,76}=25.400,-$ \\
\hline 2 & $1 \mathrm{~ms}: 1 \frac{1}{2} \mathrm{lb}$ & $\begin{array}{l}0,1 \text { supervisor : } 5.000,- \\
1 \text { mason }: 40.000,- \\
11 \frac{1}{2} \text { labor: } 37.500,-\end{array}$ & $82.500,-$ / day & 3,39 & $\frac{82.500}{3,39}=24.400,-$ \\
\hline 3 & $1 \mathrm{~ms}: 2 \mathrm{lb}$ & $\begin{array}{l}0,1 \text { supervisor : } 5.000,- \\
1 \text { mason : } 40.000,- \\
2 \text { labor : } 50.000,-\end{array}$ & $95.000,-$ / day & 4,08 & $\frac{95.000}{4,08}=23.300,-$ \\
\hline 4 & $1 \mathrm{~ms}: 2^{1 / 2} \mathrm{lb}$ & $\begin{array}{l}0,1 \text { supervisor : } 5.000,- \\
1 \text { mason : } 40.000,- \\
21 / 2 \text { labor }: 75.000,-\end{array}$ & 107.500,- / day & 4,26 & $\frac{107.500}{4,26}=25.300,-$ \\
\hline 5 & $1 \mathrm{~ms}: 3 \mathrm{lb}$ & $\begin{array}{l}0,1 \text { supervisor : } 5.000,- \\
1 \text { mason : } 40.000,- \\
3 \text { labor : } 100.000,-\end{array}$ & 120.000,- / day & 4,32 & $\frac{120.000}{4,32}=27.800,-$ \\
\hline
\end{tabular}

TABLE 9.

Kinds of Labor Group, Composition, MeAn Productivity, CONDitions For data SufFiciency, Productivity COST

\begin{tabular}{|c|c|c|c|c|c|c|c|}
\hline No & $\begin{array}{l}\text { Kinds of } \\
\text { Labor } \\
\text { Group }\end{array}$ & Composition & $\begin{array}{c}\text { Mean } \\
\text { Productivity } \\
\text { (unit) }\end{array}$ & & $\begin{array}{c}\mathrm{N}^{*} \\
\text { (Conditions } \\
\text { for data } \\
\text { sufficiency) } \\
\end{array}$ & $\begin{array}{c}\text { Productivity } \\
\text { Cost/Unit } \\
\text { (Rp./unit) }\end{array}$ & $\begin{array}{c}\mathrm{N} \\
\text { (Sample } \\
\text { Amount) }\end{array}$ \\
\hline 1 & Bricklaying & $\begin{array}{c}1 \mathrm{~ms}: 1 \mathrm{lb} \\
1 \mathrm{~ms}: 1 \frac{1}{2} \mathrm{lb} \\
1 \mathrm{~ms}: 2 \mathrm{lb} \\
1 \mathrm{~ms}: 2 \frac{1}{2} \mathrm{lb}\end{array}$ & $\begin{array}{r}1 ., 02 \\
1.22 \\
1.45 \\
1.49\end{array}$ & $\begin{array}{l}\mathrm{m}^{3} \\
\mathrm{~m}^{3} \\
\mathrm{~m}^{3} \\
\mathrm{~m}^{3}\end{array}$ & $\begin{array}{c}11.9 \\
12,40 \\
9,30 \\
9,97\end{array}$ & $\begin{array}{l}68.627,-/ \mathrm{m}^{3} \\
67.622,-/ \mathrm{m}^{3} \\
65.517,-/ \mathrm{m}^{3} \\
72.150,-/ \mathrm{m}^{3}\end{array}$ & 20 \\
\hline \multirow[t]{2}{*}{2} & \multirow[t]{2}{*}{$\begin{array}{c}\text { Wall } \\
\text { plastering }\end{array}$} & $1 \mathrm{~ms}: 1 \mathrm{lb}$ & 16.43 & $\mathrm{~m}^{2}$ & 14,57 & $4.260,-/ \mathrm{m}^{2}$ & \\
\hline & & $\begin{array}{c}1 \mathrm{~ms}: 1 \frac{1}{2} \mathrm{lb} \\
1 \mathrm{~ms}: 2 \mathrm{lb} \\
1 \mathrm{~ms}: 2 \frac{1}{2} \mathrm{lb}\end{array}$ & $\begin{array}{r}22.3 \\
24.4 \\
24.75 \\
\end{array}$ & $\begin{array}{l}\mathrm{m}^{2} \\
\mathrm{~m}^{2} \\
\mathrm{~m}^{2}\end{array}$ & $\begin{array}{c}11,90 \\
7,45 \\
10,05\end{array}$ & $\begin{array}{l}3.699,-/ \mathrm{m}^{2} \\
3.837,-/ \mathrm{m}^{2} \\
4.343,-/ \mathrm{m}^{2}\end{array}$ & \\
\hline
\end{tabular}

TABLE 10.

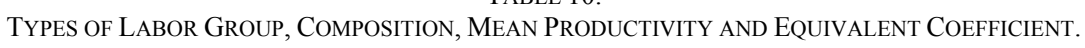

\begin{tabular}{|c|c|c|c|c|c|}
\hline \multirow{2}{*}{$\frac{\text { No }}{1}$} & \multirow{2}{*}{$\begin{array}{c}\begin{array}{c}\text { Kind of Labor } \\
\text { Group }\end{array} \\
\text { Masonry }\end{array}$} & Composition & \multicolumn{2}{|c|}{$\begin{array}{l}\text { Mean Productivity } \\
\text { (unit) }\end{array}$} & \multirow{2}{*}{$\begin{array}{c}\begin{array}{c}\text { Equivalent } \\
\text { Coefficient }\end{array} \\
0,68\end{array}$} \\
\hline & & 1 mason : 1 labor & 2,76 & $\mathrm{~m}^{3}$ & \\
\hline & & 1 mason : $1 \frac{1}{2}$ labor & 3,39 & $\mathrm{~m}^{3}$ & 0,83 \\
\hline & & 1 mason : 2 labor & 4,08 & $\mathrm{~m}^{3}$ & 1,00 \\
\hline & & 1 mason : $2 \frac{1}{2}$ labor & 4,26 & $\mathrm{~m}^{3}$ & 1,05 \\
\hline & & 1 mason : 3 labor & 4,32 & $\mathrm{~m}^{3}$ & 1,06 \\
\hline \multirow[t]{4}{*}{2} & Bricklaying & 1 mason : 1 labor & 1,02 & $\mathrm{~m}^{3}$ & 0,70 \\
\hline & & 1 mason : $1 \frac{1}{2}$ labor & 1,22 & $\mathrm{~m}^{3}$ & 0,84 \\
\hline & & 1 mason : 2 labor & 1,45 & $\mathrm{~m}^{3}$ & 1,00 \\
\hline & & 1 mason : $2 \frac{1}{2}$ labor & 1,49 & $\mathrm{~m}^{3}$ & 1,03 \\
\hline \multirow[t]{4}{*}{3} & Wall plastering & 1 mason : 1 labor & 16,43 & $\mathrm{~m}^{2}$ & 0,74 \\
\hline & & 1 mason : $1 \frac{1}{2}$ labor & 22,30 & $\mathrm{~m}^{2}$ & 1,00 \\
\hline & & 1 mason : 2 labor & 24,40 & $\mathrm{~m}^{2}$ & 1,10 \\
\hline & & 1 mason : $2 \frac{1}{2}$ labor & 24,75 & $\mathrm{~m}^{2}$ & 1,11 \\
\hline
\end{tabular}

Table 11.

Productivity Difference of Mason from Research Result of SNI 2001

\begin{tabular}{|c|c|c|c|c|c|c|}
\hline No & Kinds of Activity & $\begin{array}{l}\text { Mean of Productivity } \\
\text { Research Resuls }\end{array}$ & $\begin{array}{l}\text { Mean of Productivity } \\
\text { Post-equivalency }\end{array}$ & $\begin{array}{c}\text { Mean of Productivity } \\
\text { SNI 2001* }\end{array}$ & \multicolumn{2}{|c|}{ Difference ( \% ) } \\
\hline 1 & Masonry & $\begin{array}{c}4,08 \mathrm{~m}^{3} \\
1 \mathrm{~ms}: 2 \mathrm{lb}\end{array}$ & $\begin{array}{c}4,17 \mathrm{~m}^{3} \\
1 \mathrm{~ms}: 2 \frac{1}{2} \mathrm{lb}\end{array}$ & $\begin{array}{c}2 \mathrm{~m}^{3} \\
1 \mathrm{~ms}: 2 \frac{1}{2} \mathrm{lb}\end{array}$ & $2,17 \mathrm{~m}^{3}$ & $108,50 \%$ \\
\hline 2 & Bricklaying & $\begin{array}{c}1,45 \mathrm{~m}^{3} \\
1 \mathrm{~ms}: 2 \mathrm{lb}\end{array}$ & $\begin{array}{l}1,49-1,50 \mathrm{~m}^{3} \\
1 \mathrm{~ms}: 3,2 \mathrm{lb}\end{array}$ & $\begin{array}{c}1,26 \mathrm{~m}^{3} \\
1 \mathrm{~ms}: 3,2 \mathrm{lb}\end{array}$ & $0,24 \mathrm{~m}^{3}$ & $19,00 \%$ \\
\hline 3 & Wall plastering & $\begin{array}{c}22,3 \mathrm{~m}^{3} \\
1 \mathrm{~ms}: 1 \frac{1}{2} \mathrm{lb}\end{array}$ & $\begin{array}{c}20,54 \mathrm{~m}^{3} \\
1 \mathrm{~ms}: 1,34 \mathrm{lb}\end{array}$ & $\begin{array}{c}8,04 \mathrm{~m}^{3} \\
1 \mathrm{~ms}: 1,34 \mathrm{lb}\end{array}$ & $12,5 \mathrm{~m}^{3}$ & $155,50 \%$ \\
\hline
\end{tabular}

* The effective man-hour is 6 man-hours multiplied with 1,20 x standard of SNI 2001 (5 man-hour) 


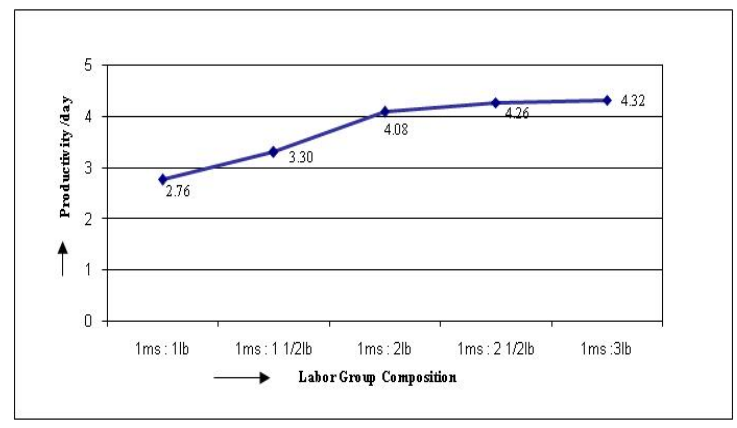

Fig.1. Plot between mason group composition and daily productivity.

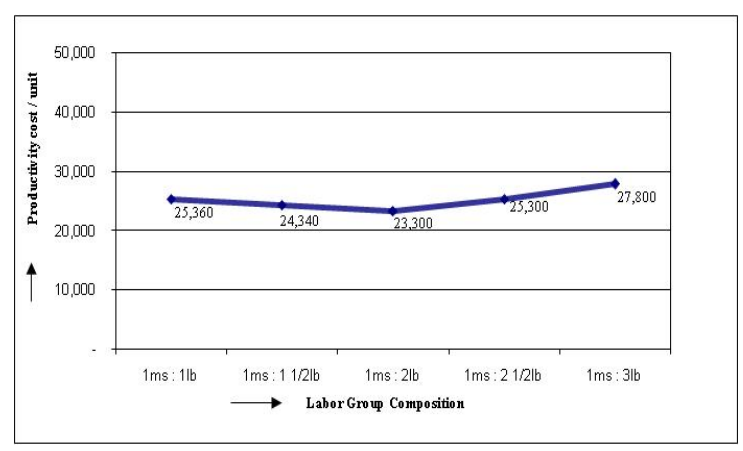

Fig. 2. Plot between mason labor group composition and productivity cost

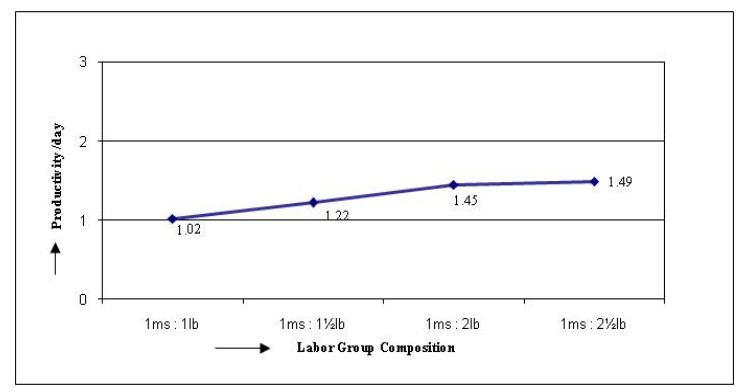

Fig. 3. Plot between bricklaying labor group composition and daily productivity

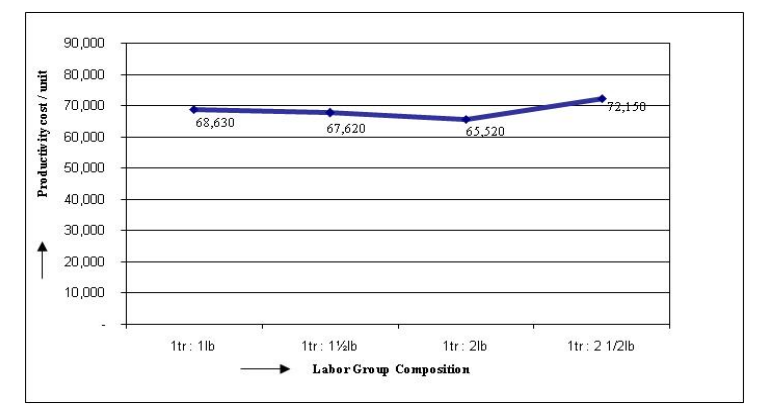

Fig. 4. Plot between bricklaying labor group composition and productivity cost

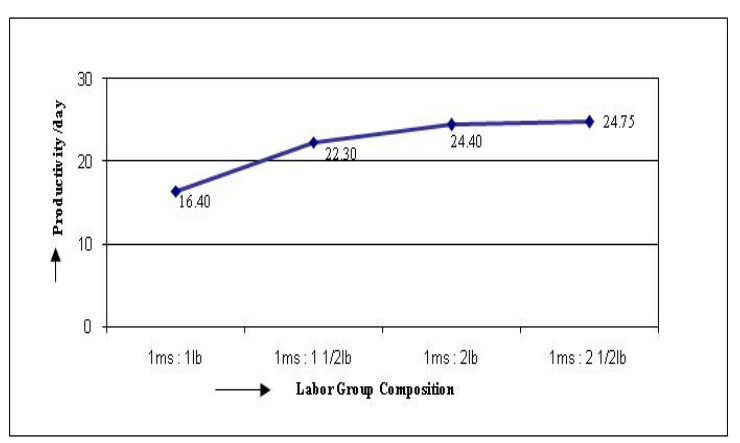

Fig. 5. Plot between wall plastering labor group and daily productivity

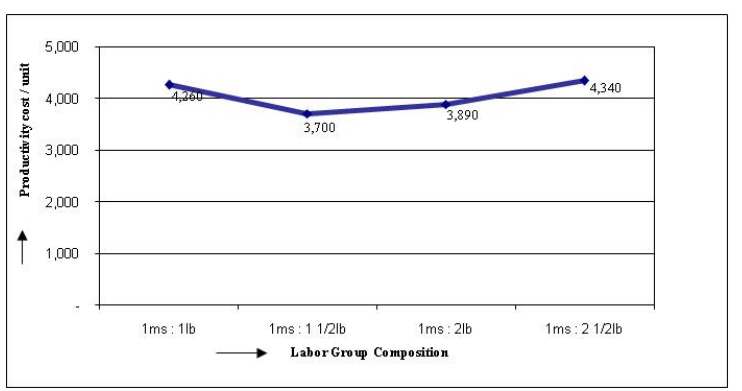

Fig. 6. Plot between wall plastering labor group and productivity cost 